\title{
DEVELOPMENT OF INTERNATIONAL TAX LAW IN THE AMERICAS
}

\author{
Mitcheli B. Carroli*
}

The provision in the Revenue Act of I94I (Section I09) to reduce by treaties with other countries of the Western Hemisphere the income tax withheld at source in the case of certain taxpayers resident therein reflects the movement to develop international tax law which made ever-increasing headway during the two decades subsequent to the Peace of Versailles. Progress in the prevention of international double taxation, as well as of extraterritorial and discriminatory taxation, has been realized partly through unilateral restrictions on a government's fiscal jurisdiction by internal legislation, and partly through reciprocal treaties.

The United States Congress has in effect delegated, in the above provision which amends Sections 2II and 23I of the Internal Revenue Code, specific authority to the Executive to reduce the withholding rate of $2712 \%$ to a rate not less than $5 \%$ in treaties with countries of North, Central, and South America, the West Indies (including Cuba and Bermuda), and Newfoundland. Previously, such a reduction could be made only in treaties with contiguous countries, i.e., Canada and Mexico, and a treaty had been concluded with the former.

The reduceable rate is applicable to dividends payable to corporations organized in such countries and not doing business in the United States (Section 23I (a) (I)) and to dividends, interest, royalties, and other fixed or determinable annual or periodical income from United States sources derived by aliens resident in such countries and not doing business in the United States (Section 2II (a) (I) (A)). The tax of $271 / 2 \%$ is withheld from the gross amount of such income derived by nonresident aliens up to an amount equal to $\$ 23,000$, at which figure such taxpayers are required to file returns and pay a tax on the net amount of such income. Nonresident aliens deriving a lesser amount of such income usually bear a heavier tax than citizens of the United States in respect of the same amount of income.

This discrimination against taxpayers resident in other countries was pointed out

- B.A., 1920, Johns Hopkins University; Lic. en Dr., 1922, University of Paris; J. D., I923, University of Bonn; LL.B., 1927, George Washington University. Member of District of Columbia and New York State Bars, practicing in New York City. U. S. member of the Fiscal Committee, League of Nations, since r934; director of survey of tax systems of 35 nations for Fiscal Committee, I93I-I933; special attorney, U. S. Treasury Department, in international tax matters, $x 930-1931$; member, U. S. commission to negotiate double taxation treaty with France, I930; member, Conference of Government Experts on Double Taxation, Geneva, 1928; member, Conference of Technical Experts on Double Taxation, London, 1927; chief, section of European Law and Taxes, U. S. Department of Commerce, 1924-I929. Author of books on taxation and contributor to legal periodicals of articles on taxation and international tax law. 
by a former Finance Minister of Cuba at the first meeting of the Inter-American Bar Association which took place in Havana, March 24-28, I94r. He stated that, if the example of the United States in this respect were followed by other countries in this hemisphere, the results might be disastrous for inter-American business. When made aware of this danger, Congress adopted a method for removing the discrimination which at the same time enables the treaty-making states to modify tax laws and practices obstructive to trade, and in general to prevent extraterritorial and double taxation.

In other words, the amendment to the Internal Revenue Code bespeaks a policy of bringing about hemisphere economic solidarity through the adoption in treaties of principles of international tax law. It is therefore opportune to trace the broad outline of the development of such conventions.

In the days of Hugo Grotius, international tax barriers to trade were not a problem, and the Father of International Law had no occasion to include taxation in his great treatises. While, from the beginning of history, governments have had to be supported by the people, the contributions or levies of various kinds were purely local and were apparently not considered to be obstructive to trade with neighbors or nations overseas.

With the coming of the nineteenth century and the increase in governmental costs, the art of collecting taxes advanced as well. European governments had recourse to business license taxes and sought to impose these even upon foreign shipowners. The income tax, originating in Great Britain in 1799, and the tax on total wealth, developed in the Netherlands and central European states, accelerated the spread of double taxation inasmuch as states did not confine their taxes to property situated in, or income from sources in, their respective territories. Some states exercised jurisdiction over an individual's entire property or income merely on the ground of his residence within their territory; others sought to impose taxes on the total property or income of nonresident citizens, regardless of situs or source.

As international trade expanded and individuals combined their resources in corporations, tax problems increased, especially as rates soared with budgetary exigencies during and after World War No. I. The same income of a corporation doing business in two or more countries was subjected to tax both at the corporate domicil and at the income's source abroad. Branch offices in one country of corporations domiciled elsewhere were taxed on profits well in excess of those attributable to the branch's activities (whether selling or manufacture). If a subsidiary were organized either to avoid such difficulties or for other reasons, some countries extended their fiscal arms abroad to reach the parent corporation-and sometimes even a grandparent corporation. And if any income survived these taxes, then the woes of the shareholders began. A tax on dividends might be withheld at the source while the same dividends were subjected to tax at the shareholder's domicil. And, if he collected through a paying agent in a third country, it too might withold a tax. 
The movement of goods was obstructed by subjecting them to both export and import taxes and by levying license taxes on both exporters and importers. Stamp taxes were imposed on bills of lading and drafts by both shipping and receiving countries. Traveling salesmen and their employers were subjected to taxes in foreign countries, even when the salesmen's visits were brief, and again at their homes.

There were some efforts in the nineteenth century to deal with these evils by legislation and treaty, the first measure known to the author being a Netherlands law of $18 \mathrm{I} \mathrm{g}^{1}$ which exempted foreign shipowners from the Dutch business license tax provided Dutch shipowners were given a reciprocal exemption. However, the movement for the prevention of double taxation has been particularly active since the Peace of Versailles. Business men found their post-war efforts to renew commercial relations seriously hampered by the cumulation of high rates on the same income or property in two or more countries. Mainly through the International Chamber of Commerce, they called for relief from their governments ${ }^{2}$ which began to take unilateral measures of relief, ${ }^{3}$ to conclude treaties, ${ }^{4}$ and to participate in the meetings of experts convened under the auspices of the League of Nations to formulate a uniform procedure..$^{5}$

Various governments have realized the wisdom of giving up a tax on a certain kind of activity, income, or property, in order to derive a larger benefit from the

${ }^{3}$ Netherlands, Law of May 2I, I8Ig, table XVI(E), (r8rg) StaAtsbiad no. 34.

${ }^{2}$ See International Chamber of Commerce, Brochures II, 25, 34, 60 .

${ }^{3}$ See, e.g., Netherlands, Law of April I6, I920, (1920) StaAtsBLAd no. I92.

- One of the first of the post-war double taxation treaties was signed by Czechoslovakia and Germany on Dec. 31, 1921. I Collection of International Agreements and Internal Legal Provisions for the Prevention of Double Tasation and Fiscal Evasion (prepared by the Economic and Financial Section of the Secretariat of the League of Nations in accordance with the Council Resolution of September 15, 1927) (hereinafter referred to as L. N. CoLL.) (1928) 9, L. N. Doc., C. 345. M. I02. I928. II. For similar agreements, see this and the subsequent five volumes of this collection: 2 L. N. CoLL. (x929), C. 365. M. 134. 1929. II.; 3 L. N. CoLL. (1930), C. 585. M. 263. 1930. II.; 4 L. N. CoLL. (193I), C. 79I. M. 385. 1931. II. A.; 5 L. N. Colr. (1933), C. 618. M. 29I. 1933. II. A.; 6 L. N. Colt. (r936), C. I18. M. 57. 1936. II. A. For some of the agreements prior to I9I4, see also 4 RosenDorfr AND HENGGeler, Internationales Steuerrectrt des Erdballs (Basel, i938) I74I (looseleaf), and I L. N. Coll. (1928) 249.

'See Report on Double Taxation, submitted to the Financial Committee by Professors Bruins, Einaudi, Seligman and Sir Josiah Stamp (x923), L. N. Doc., E. F. S. 73/F rg; Double Taxation and Tax Evasion: Report and Resolutions submitted by the Technical Experts to the Financial Committee of the League of Nations (I925), L. N. Doc., C. 368. M. Ix5. I925. II.; Report presented by the Committee of Technical Experts on Double Taxation and Tax Evasion (1927) (hereinafter referred to as L. N. ReP. 1927), L. N. Doc., C. 216. M. 85. 1927. IJ.); Report presented by the General Meeting of Government Experts on Donble Taxation and Tax Evasion (1928) (hereinafter referred to as L. N. Rep. I928), L. N. Doc., C. 562. M. 178. 1928. II.; Report to the Council on the Work of the First Session of the Fiscal Committee (r929) (hereinafter referred to as Fiscal Com. Rep.), L. N. Doc., Ist Sess. (x929), C. 516. M. 175. I929. II.; for succeeding reports, see 2d Sess. (1930), C. 340. M. x40. 1930. II.; 3rd Sess. (193I), C. 415. M. 17I. 1931. II. A.; 4th Sess. (1933), C. 399. M. 204. 1933. II. A.; 5th Sess. (I935), C. 252. M. 124. 1935. II. A.; 6th Sess. (1936), C. 450. M. 266. 1936. II. A.; 7th Sess. (1937), C. 490. M. 331. x937. II. A.; 8th Sess. (1938), C. 384. M. 229. 1938. II. A.; 9th Sess. (1939), C. 181. M. 110. 1939. II. A.; 10th Sess. (1940) (in 2 parts, mimeographed) F./Fiscal/126 and 127; Mitchell B. Carroll, Prevention of International Double Taxation and Fiscal Evasion: Two Decades of Progress under the League of Nations (1939), L. N. Doc. F./Fiscal/rux. 
increased commerce that should result. Broadly speaking, depending upon their economic interests, they have followed one or more of the following procedures.

\section{Provisions Beneficial to Aliens and Foreign Corporations}

The surrendering or restricting of their tax jurisdiction over the activities, income or property of aliens and foreign corporations in their territory, sometimes on condition of reciprocity, sometimes unconditionally.

\section{(a) Exemption of shipping and air navigation enterprises}

A century after the Netherlands reciprocal exemption law, ${ }^{6}$ the United States decided it would be wise to cease struggling with the problem of trying accurately to determine the income earned in the United States from the operation of ships by the citizens or corporations of foreign countries, and offered to exempt them if a reciprocal exemption were accorded to American shipping enterprises. ${ }^{7}$ During the last two decades this so-called principle of reciprocal exemption has been embodied in over seventy understandings concerning shipping profits between maritime countries, ${ }^{8}$ as well as in numerous general tax treaties. ${ }^{9}$ With the development of aviation, and especially in view of the large extent to which air transport enterprises are subsidized by their governments through mail contracts or otherwise, this rule has also been applied to such enterprises in some legislation ${ }^{10}$ and in over five special agreements on the subject, ${ }^{11}$ as well as in several more general tax conventions. ${ }^{12}$

\section{(b) Exemption of sales through brokers and commission agents}

Countries interested in developing their home markets for raw materials, other commodities and securities have also found it expedient to exempt income derived by foreign enterprises on sales of such commodities or securities through local commission agents or brokers, and to limit their tax jurisdiction to the earnings of such agents or brokers. They found it practically impossible to determine the income of the foreign enterprises derived from such transactions because of their inability to ascertain costs and the difficulties in separating hedging transactions, speculative dealings, and transactions in an actual commodity. Furthermore, attempts to collect the tax merely drove the business to other exchanges or markets. This exemption has been granted by legislation, in most cases unconditionally, ${ }^{13}$ and has been incor-

${ }^{\circ}$ See supra note $\mathrm{I}$.

${ }^{7}$ Revenue Act of rg2r, $\$ \$ 213$ (b) (8) and 233, 42 STAT. 239 and 254 (I92I), now 26 U. S. C. A. $\$ \$ 212$ (b) and 231 (d) (1940).

${ }^{8}$ See, e.g., Greece and the Netherlands: Agreement Relative to Shipping Profits, Dec. 5, 1930, 5 L. N. Coll. (1933) 75; see, generally, L. N. Coln., passim. Since the publication of the last volume of this set in 1936, mimeographed texts of individual treaties have been issued in a series entitled League of Nations, Fiscal Committee, International Agreements and Internal Legal Provisions for Prevention of Double Taxation and Fiscal Evasion.

${ }^{-}$See, e.g., Denmark and Sweden: Agreement on Double Taxation, May 6, r932, art. 6, 5 L. N. Coll. (x933), 52; see generally note 8, supra.

${ }_{10}$ See, e.g., Great Britain: Finance Act, 1923, $\$ 18, I_{3}$ \& I4 Geo. V, c. I4, 18 , as amended by Finance Act, 1931, \$9, 21 \& 22 Geo. V, c. 28, \$9.

${ }^{11}$ See, e.g., France and Great Britain: Agreement on Air Transport Profits, April 9, 1935, 6 L. N. CoLL. (r936) 60 .

${ }^{12}$ See note 9, supra.

${ }^{13}$ See, e.g., U. S. INT. Rev. Cone $\$ 2 I I$ (a) (I) (A), (b), and (c) (I), \$23I (a) (I) and (b), 53 StaT. $75,76,78$ (1939), 26 U. S. C. A. $\$ 21 I$ (a) (I) (A), (b), and (c) (I), \$23I (a) (I) and (b) (I940). 
porated in about twenty special agreements ${ }^{14}$ and some sixty general conventions. ${ }^{15}$

(c) Exemption of traveling representatives

To facilitate the development of commercial relations, some countries have found it expedient to refrain from taxing the foreign traveling and other business representatives, who come into the country to sell the goods of their employer or to purchase local products, in respect of income earned while in the country during brief visits. ${ }^{10}$ The amount of tax involved is usually small and is not sufficient to justify the trouble involved and the ill will often engendered in trying to collect the levy. Furthermore, such persons are generally subject to income tax in the countries where they normally reside, and the imposition of a levy on earnings in the country visited constitutes burdensome double taxation.

(d) "Purchasing profit" exempt

Furthermore, to encourage the export of their products, most countries exempt any profit considered to be derived by a foreign enterprise from purchasing local products through an agency or branch. ${ }^{17}$ No profit is actually derived by the foreign enterprise until the products purchased in the country are sold abroad, and it is impossible to determine what part of the profit, if any, is attributable to the act of purchase in the country.

\section{(e) Allocation to branches: Rules of Fiscal Committee}

Most countries in their laws ${ }^{18}$ or treaties ${ }^{19}$ have restricted their jurisdiction over a foreign corporation with a branch establishment of some kind within their territory to the profit attributable to the activities of the branch as distinguished from those attributable to the head office and branches in other countries. Thus if a foreign enterprise manufactures abroad and merely sells its goods at the establishment within a country, the latter taxes only the profit attributable to selling and leaves the profit attributable to manufacture to be taxed where the factory is situated. On the other hand, if the foreign enterprise produces a raw material, such as a mineral or agricultural product, in one country and sells it at a branch in a second, the former country should limit the basis of its tax to the profit attributable to production and leave to the country of sale the taxation of the sales profit.

This raises the question as to how the profit should be divided between the different countries. After studying the matter during three years, ${ }^{20}$ the Fiscal Com-

${ }^{14}$ See, e.g., Great Britain and the Netherlands: Convention on Agency Profits, June 6, I935, 6 L. N. Colz. (1936) 49. See generally note 8, supra.

${ }^{25}$ See, e.g., France and the United States: Convention on Taxation, art. I and prot., no. 3 (a), 5 L. N. Colz. (I933) 48. See generally note 8, supra.

${ }^{10}$ See, e.g., U. S. INT. Rev. CODE, $₫$ II9 (a) (3) 53 STAT. 54 (1939), 26 U. S. C. A. II9 (a) (3) (I940).

${ }^{17}$ See, e.g., Great Britain: Sulley v. Attorney General, 5 H. and N. 7II, 2 T. C. 149 (I860).

${ }^{28}$ See, e.g., U. S. INT. Rev. Code, §II9 (e), 53 STAT. 55 (x939), 26 U. S. C. A. II9 (e) (1940); INT. REv. REG. I03, §I9. II9-12 (I940).

${ }^{10}$ See, e.g., Danzig and Poland: Agreement on Direct Taxes, May 29, 1929, art. III, 2 L. N. Coll. (1929) 9. See generally note 8 , supra.

${ }^{20}$ Much of the source material for this study is found in Taxation of Foreign and National EnterpRIsEs, L. N. Docs., vol. I (1932), C. 73. M. 38. I932. II. A.; vol. 2 (1933), C. 425. M. 217. 1933. II. A.; 
mittee of the League of Nations drew up a draft convention embodying its decision that the most practical solution would be for countries to conclude agreements stipulating that an enterprise of one country having a permanent establishment in the other should keep for such establishment separate accounts which would reflect the net income it would derive if it were an independent enterprise engaged in the same or similar activities under the same or similar conditions. ${ }^{21}$ Accordingly, transactions between such establishment and the rest of the enterprise would be reflected in its books at the same prices that would prevail if it were entering into a contract with an independent enterprise. Such prices can generally be verified by a comparison with actual dealings with third parties, or by published list prices or known market prices. ${ }^{22}$ A procedure for making a presumptive assessment in case the tax declaration cannot be readily verified is also contained in this draft convention. ${ }^{23}$

\section{(f) Exemptions or low rates to attract foreign capital}

To attract foreign capital, some countries have specifically exempted interest on foreign loans to domestic corporations, as was done by Germany ${ }^{24}$ and Italy, ${ }^{25}$ and to attract the investment by foreigners in shares of local companies, they have either refrained from taxing dividends (e.g., Italy) ${ }^{26}$ or have applied only a low withholding rate (e.g., Canada where the rate, until April 30, I94I, was $5 \%{ }^{27}$ ).

\section{(g) Patent and copyright royalties}

Moreover, to encourage the development of local industries, governments, in concluding tax treaties, have often limited themselves to the taxation of the profit derived within their territory from the exploitation of the rights under patents and copyrights and have exempted the royalties paid to licensors residing abroad, so that they will be taxed only in the country where the recipient resides. ${ }^{28}$

\section{Provisions to Help Nationals and Domestic Corporations}

The foregoing represent concessions made to foreigners, but out of enlightened self-interest countries have helped their own nationals and domestic corporations, with business establishments or other investments in a foreign country, by acknowledging the prior right of the latter state to tax income from sources therein and giving some relief from the home tax in respect of such income. By such a unilateral

vol. 3 (I933), C. 425 (a). M. 217 (a). 1933. II. A.; vol. 4 (1933), C. 425 (b). M. 217 (b). 1933. II. A.; vol. 5 (I933), C. 425 (c). M. 217 (c). 1933. II. A. The results of the study are: Draft Convention for the Allocation of Business Income, Frscal CoM. Rep. (1933) 3; Revised Text of the Draft Convention for the Allocation of Business Income, and Allocation of Income of Insurance Enterprises, Fiscal CoM. REP. (1935) 5; Allocation of Income of Insurance Enterprises, Fiscal CoM. Rep. (1936) 7 .

${ }_{21}$ Revised Text of the Draft Convention for the Allocation of Business Income, art. III ( $\mathrm{r}$ ), Fiscat CoN. REP. (1935) 5 . 22 Id. art. III (2).

${ }^{23}$ Id. art. III (3) and (4).

24 Laws of June 9, r930, and Oct. I6, I930 (I930) Rabl. I, 187 and 464 .

${ }^{25}$ Decree-laws 1634 of Dec. I6, I922, and 1643 of Sept. 20 , 1926, art. 10, (1922) R. L. D. 4987 , and (1926) R. L. D. 6897.

${ }^{26}$ Decree 4021 of Aug. $24 ;$ i877, (1877) R. L. D. 2162, as amended, 2 TAXATION on ForEIGN AND NATIONAL ENTERPRises, supta note 20, at 246 .

${ }^{27}$ Income War Tax Act, $\$ 9 B$ (2) (a), Stat. 1927, c. 97, as amended by Amendment Act, $\$ 9$, Stat. I932-33, c. $4 \mathrm{I}$.

${ }^{28}$ See, e.g., Belgium and France: Convention on Double Taxation, May I6, 1931, arts. 9 \$2, and 7, 5 L. N. Corl. (1933) 58. 
measure a country encourages its nationals and corporations to trade abroad and bring their income home where it increases the wealth of the country when paid for goods or as salaries, dividends and interest. The Netherlands was a pioneer in this type of relief. In 1893 it permitted a resident individual deriving income from a Dutch colony to deduct from the graduated tax payable to the Netherlands the tax he had paid in such colony. This deduction has since been extended to cover taxes paid to a foreign country. 29

The same principle is found in the laws of France ${ }^{30}$ and Italy ${ }^{31}$ which exempt domestic enterprises from profits tax in respect of business income allocable to a permanent establishment in another state; and this principle has been incorporated in most of the general bilateral treaties, over sixty in number, to which European states have become parties since $1920 .{ }^{32}$ The credit for foreign taxes allowed by the United States has the same effect with limitations. ${ }^{33}$

\section{Trend of Treaties-The Mexico City Draft}

Largely due to the pioneer work of a series of committees of the League of Nations culminating in the Fiscal Committee, ${ }^{34}$ which has had throughout the collaboration of the International Chamber of Commerce, ${ }^{35}$ there has been a trend during the last two decades to negotiate bilateral treaties embodying solutions to prevent double taxation of all categories of income in the manner outlined above. The network of bilateral treaties between European countries, embodying essentially the same principles, constitutes in effect a multilateral treaty. ${ }^{36}$ A synthesis of the most up-to-date provisions in the sixty-odd general treaties and of model conventions relative to the taxation of income formulated by the League committees, ${ }^{37}$ as well as of the League draft convention on the allocation of business income for tax purposes, ${ }^{38}$ is found in the model convention adopted as a first reading by a regional meeting of the Fiscal Committee at Mexico City, June 3-15, I940. ${ }^{39}$

The meeting was attended by experts from Argentina, Brazil, Mexico, Peru and

${ }^{20}$ Income Tax Law of Oct. 2, I893, art. 37, (1893) StaAtsblad no. I49; Ministerial Decree of April 17, 1928, art. I (a), (1928) StAATSBLAD no. 76.

${ }^{30}$ Code of Direct Taxes, art. 2, J. O., Dec. 29, r934.

${ }^{31}$ Decree-law I463 of Aug. 12, 1927, art. 9, (1927) R. L. D. 6907.

${ }^{38}$ See, e.g., Belgium and the Netherlands: Convention on Double Taxation, Feb. 20, I933, art. 4, \$2, 6 L. N. Corc. (1936) 9. See, generally, note 8, supra.

${ }^{38}$ See U. S. Int. Rev. Code, $\$ 131,53$ Stat. 56 (1939), as amended by Revenue Act of 1939, \$216 (b), 53 StaT. 876 (1939), 26 U. S. C. A. \$I III (r940).

su See note 5, stpra.

${ }^{35}$ See L. N. REP. 1927, 7; Fiscal CoMr. REP (1939) I; see also note 2, supra.

${ }^{30}$ See note 8, supra.

${ }^{37}$ For the agreements, see note 8, supra; for the League drafts, see Draft of a Bilateral Convention for the Prevention of Double Taxation, L. N. Rep. 1927, ro; Bilateral Conventions for the Prevention of Dosble Taxation in the Special Matter of Direct Taxes, L. N. Rep. 1928, 7; Draft Plurilateral Convention for the Prevention of Double Taxation of Certain Categories of Income, Draft Plurilateral Convention " $A$ " for the Prevention of the Double Taxation of Certain Categories of Income, and Draft Plurilateral Convention "B," FisCAL CoMr. ReP. (193I) IO.

${ }^{38}$ See note 20 , supra.

${ }^{30}$ Draft Revision of the Model Bilateral Convention No. I (c) for the Prevention of Double Taxation in the Field of Direct Taxes Framed by the General Meeting of Government Experts of 1928, FiscaL Coss. Rep. (1940), pt. 2 (designated as $2 \mathrm{~d}$ rep.) 2. 
Venezuela, as well as Canada and the United States. Hence it contains the results of a joint effort of experts from many of the states of the Western Hemisphere to formulate a model that can be followed in negotiating bilateral treaties among themselves. It is an important step in developing international tax law in the Americas with a view to facilitating commercial intercourse.

\section{Relation of Tax Treaties to Commercial Treaties}

There already exist between various countries of this hemisphere two general categories of treaties affecting business: (I) trade agreements concerning the rates of duty to be applied upon the importation into one High Contracting Party of the products of the other Party, ${ }^{40}$ and (2) treaties of friendship, commerce and consular rights. ${ }^{41}$ The latter category is intended to govern the rights of the citizens and corporations of one High Contracting Party to enter the territory of the other, open business establishments, acquire property, employ agents, have access to the local courts, and in general exercise the rights and enjoy the protection that is necessary for commercial intercourse. Such agreements generally contain a clause that the nationals of one country within the territory of the other shall not be subject to other or higher taxes than nationals of such other country ${ }^{42}$ but obviously such a clause should be supplemented by rules specifically formulated to define tax jurisdiction in such a way as to encourage mutual trade.

\section{Basis for Inter-American Treaty Regime}

To complete the treaty regime, tax treaties should also be concluded along the lines of the Mexican City draft so as to remove unnecessary obstacles to trade, and prevent extraterritorial, discriminatory, and double taxation.

These unnecessary obstacles are removed by

I) reciprocal examination of shipping and air navigation profits (Mexico City model convention, art. 5);

2) reciprocal exemption of sales through traveling salesmen, commission agents and brokers (art. 4);

3) reciprocal exemption of business visitors from one country who are in the other for less than r8o days in the aggregate during the taxable year (art. 7 (I)).

Extraterritorial taxation is prevented by the provision that a contracting state should tax the business income of an enterprise of the other state only to the extent that it is allocable to a permanent establishment within the former's territory (art. 4), and by the rules of allocation in the protocol.

There may also be occasion to preclude the extraterritorial application of a country's dividend tax to dividends distributed abroad by a foreign company to its shareholders resident abroad.

\footnotetext{
${ }^{40}$ See, e.g., Colombia and United States: Agreement on Reciprocal Trade, Sept. 13, I935, U. S. Exzc. Agr. Ser., No. 89 (I936), i70 League of Nations Treaty Ser. 293 (1936-37).

${ }^{4}$ See, e.g., Salvador and United States: Treaty on Friendship, Commerce, and Consular Rights, Feb. 22, I926, passim, U. S. Treaty Ser., No. 827 (1930), i34 League of Nations Treaty Ser. 207 (1932-33).

${ }^{42}$ Id. art. I, par. 2.
} 
Discriminatory taxation should be precluded by a general clause for that purpose (art. 15), as well as a special clause providing for the reduction of taxes, on dividends, interest, and other recurring items to $5 \%$ or to such intermediate rate as may be agreeable to the contracting states. ${ }^{43}$ This clause would also have the effect of removing an obstruction to the flow of capital needed in business.

Double taxation is avoided by alloting income for tax purposes either to one state or to the other (e.g., business income should be taxable only at the permanent establishment at which produced, but royalties only in the country of the licensor), or by recognizing that the state of source has a prior right to tax, and by requiring that the state of residence of the recipient grant a reduction in its tax (e.g., a dividend tax withheld at source might be credited against the tax paid in the country of residence of the recipient). This reduction in the tax of the state of residence might be limited by the proviso that the reduction may not exceed the amount of the tax paid at source, or the amount of the tax at residence corresponding to the income involved, whichever is the lesser.

While all the bilateral treaties concluded on the basis of the Mexico City model might contain the same basic principles, their respective clauses could be adapted to meet the differences in the tax structure and provisions in the laws of the contracting states. They should be designed to fulfil the dual purpose of:

r) protecting an enterprise against overlapping assessments which would result in its being taxed on more than $100 \%$ of its income, and

2) providing the criteria whereby each interested country will have the proper basis for its tax, and a simple means whereby it can cooperate to assure a fair application of the treaty.

If most of the countries of the Americas would become parties to such agreements, their citizens and corporations would benefit from the definite assurance that the same basic principles of law would be applied practically throughout the hemisphere, and this should encourage freer commercial intercourșe.

At the meeting of the Inter-American Bar Association in Havana in March, I94I, mentioned at the beginning of this article, a committee was created to study instances of double, extraterritorial and discriminatory taxation between countries of the Western Hemisphere and to help promote the conclusion of treaties for the removal of this type of obstruction to inter-American trade. Moreover, the Fiscal Committee of the League of Nations, which has transferred its activities to the Western Hemisphere, is also planning to continue its pioneering work in this field.44

${ }^{4}$ Cf. U. S. INT. Rev. CODE, $\$ \$ 2 I I$ (a) (I) (A) and 231 (a) (I), 53 STAT. 75 and 78 (I939), 26

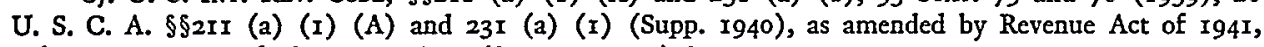
Pub. L. No. 250, 77th Cong., Ist Sess. (Sept. 20, r94I) §109.

"The headquarters of the Committee, of which the author is chairman, is now at Princeton University, where a selected staff of the Financial and Economic Sections of the League Secretariat are carrying on their work under Mr. Alexander Loveday. Mr. Paul Deperon, the Secretary of the Fiscal Committee, is now making a survey in the larger Latin American republics with a view to advancing the work done at the Mexico City meeting in June 1940. 